\title{
Pengaruh Persepsi Mahasiswa Mengenai Kompetensi Dosen dan Lingkungan Belajar Terhadap Motivasi Belajar
}

\author{
Bahrudi Efendi Damanik ${ }^{1}$, Eka Irawan ${ }^{2}$ \\ ${ }^{1,2}$ Manajemen Informatika, AMIK-STIKOM Tunas Bangsa Pematangsiantar \\ 'bahrudiefendi@gmail.com \\ ²ekairawan.@amiktunasbangsa.ac.id
}

\begin{abstract}
ABSTRAK
Tujuan penelitian adalah untuk mengetahui pengaruh persepsi mahasiswa mengenai kompetensi dosen terhadap motivasi belajar, ntuk mengetahui pengaruh lingkungan belajar terhadap motivasi belajar, dan untuk mengetahui pengaruh kompetensi dosen dan lingkungan belajar terhadap motivasi belajar. Populasi dan sampel dalam penelitian ini berjumlah 81 orang, teknik analisis data yang digunakan dalam penelitian ini adalah analisis regresi linier berganda. Persepsi mahasiswa mengenai kompetensi dosen secara partial berpengaruh positif dan signifikan terhadap motivasi belajar, thitung $>$ ttabel $(3,353>1,991)$. Lingkungan belajar secara partial berpengaruh positif dan signifikan terhadap motivasi belajar, thitung $>$ ttabel $(4,229>1,991)$. Hasil penelitian menunjukkan bahwa persepsi mahasiswa mengenai kompetensi dosen dan lingkungan belajar secara simultan berpengaruh positif dan signifikan terhadap motivasi belajar, Fhitung $>$ Ftabel yaitu $(25,872>2,720)$.
\end{abstract}

Kata kunci: Persepsi Mahasiswa, Kompetensi Dosen, Lingkungan Belajar, Motivasi Belajar

\section{ABSTRACT}

The purpose of the study was to determine the effect of student perceptions of lecturer competence on learning motivation. To determine the effect of the learning environment on learning motivation. To determine the effect of lecturer competence and learning environment on learning motivation. The population and sample in this study amounted to 81 people, and the data analysis technique used in this study was multiple linear regression analysis. Students' perceptions of lecturer competence partially have a positive and significant effect on learning motivation, tcount $>$ ttable (3.353 $>$ 1.991). The learning environment partially has a positive and significant effect on learning motivation, tcount $>$ ttable $(4,229>1,991)$. The results showed that students' perceptions of lecturer competence and the learning environment simultaneously had a positive and significant effect on learning motivation, Fcount $>$ Ftable $(25,872>2,720)$.

Keywords : Student Perceptions, Lecturer Competence, Learning Environment, Learning Motivation

\section{PENDAHULUAN}

Pendidikan dipandang sebagai salah satu aspek yang memiliki peranan pokok dalam membentuk generasi masa depan. Proses pendidikan akan mengubah tingkah laku peserta didik agar menjadi manusia dewasa yang mampu hidup mandiri dan kreatif. Dengan pendidikan, diharapkan dapat menghasilkan manusia yang berkualitas dan bertanggung jawab serta mampu menyongsong kemajuan pada masa mendatang. Pendidikan juga berfungsi mengembangkan kemampuan dan membentuk watak serta peradaban bangsa yang bermartabat karena kemajuan suatu bangsa juga dapat dilihat dari seberapa maju pendidikan yang dimiliki.

Motivasi dapat diartikan sebagai daya penggerak yang telah menjadi aktif. Motif menjadi aktif pada saat tertentu, terutama bila kebutuhan untuk mencapai tujuan sangat dirasakan atau mendesak. Motivasi yang kuat akan menumbuhkan gairah, semangat, dan perasaan senang untuk belajar. Seseorang akan menampakkan minat, perhatian, konsentrasi penuh, ketekunan tinggi, serta berorientasi pada prestasi tanpa mengenal perasaan bosan apabila ia mempunyai motivasi belajar. (Muhammad, 2017) mengatakan motivasi adalah perubahan tenaga di dalam diri seseorang yang ditandai dengan dorongan yang berasal dari diri seseorang untuk mencapai tujuan.

Secara sederhana dapat dikatakan apabila mahasiswa tidak memiliki motivasi belajar maka tidak akan terjadi kegiatan belajar pada diri mahasiswa tersebut. Apabila motivasi rendah, umumnya diasumsikan bahwa prestasi yang bersangkutan akan rendah, 
dan besar kemungkinan ia tidak akan mencapai tujuan belajar.

Dalam pengamatan penulis melalui Kartu Hasil Studi (KHS) yang dikeluarkan oleh bagian pendidikan program studi Komputerisasi Akuntansi, dampak dari kurangnya motivasi mahasiswa dalam mengikuti kuliah setelah masa perkuliahan semester selesai masih belum memuaskan, kisaran nilai yang diperoleh mahasiswa masih di angka $65-75$, atau kalau di konversi dengan nilai huruf berarti masih pada grade nilai $\mathrm{C}$ dan B.

Hal lainya juga dalam pengamatan penulis, mahasiswa yang mengikuti mata kuliah aplikasi akuntansi belum mampu mengerjakan satu kasus soal yang berisi satu siklus akuntansi dalam satu periode akuntansi tertentu. Masalah ini menjadi penting untuk diperhatikan bagi keberhasilan proses belajar mengajar agar nantinya dikemudian hari ketika mahasiswa telah selesai kuliah dapat segera mengaplikasikan ilmunya kedunia kerja, atau dunia wira usaha, juga memperoleh nilai yang baik.

\section{Persepsi Mahasiswa Mengenai Kompetensi Dosen}

Pengertian persepsi dikemukakan untuk menghindari salah tafsir tentang apa arti persepsi. (Saifuddin, 2018) menjelaskan kemauan seseorang dalam menggunakan produk teknologi sangat dipengaruhi oleh persepsi. Persepsi merupakan suatu proses yang dimulai dari penggunaan panca indera dalam menerima stimulus, kemudian diorganisasikan dan diinterpretasikan sehingga memiliki pemahaman tentang apa yang diindera.

(Sunaryo, 2004) menuliskan dalam bukunya, persepsi merupakan proses akhir dari pengamatan yang diawali oleh proses pengindraan, yaitu proses diterimanya stimulus oleh alat indra, kemudian individu ada perhatian lalu diteruskan ke otak, dan baru kemudian individu menyadari tentang sesuatu yang dinamakan persepsi

Kompetensi dosen merupakan salah satu faktor yang dapat memotivasi mahasiswa untuk belajar. Menurut (A.M., 2001), seorang mahasiswa bisa gagal karena kurang motivasi. Hasil belajar akan optimal kalau ada motivasi yang tepat. Selaras dengan ini, maka kegagalan belajar mahasiswa jangan begitu saja ditimpakan kepada mahasiswa, sebab dimungkinkan juga dosen kurang berhasil dalam memberikan motivasi yang mampu membangkitkan semangat dan keaktifan mahasiswa untuk belajar.
Dosen yang berkompeten pada umumnya dilihat dari seberapa jauh dosen menguasai materi, dapat menerapkan model pembelajaran yang tepat untuk materi yang dipelajari. Menurut (Djamarah, 2002), "Pendidik yang berkompeten adalah pendidik yang memiliki ketrampilan memberi penguatan, keterampilan bertanya, keterampilan mengadakan variasi belajar, keterampilan menjelaskan, dan keterampilan membuka dan menutup pelajaran. Dosen yang berkompeten sangat dibutuhkan dalam dunia pendidikan saat ini.

\section{Lingkungan Belajar}

Suasana lingkungan belajar yang tercipta tergantung dari bagaimana mahasiswa itu bisa mengatasi dan mengendalikan dirinya sendiri saat berada dalam lingkungan belajarnya. Lingkungan belajar oleh para ahli sering disebut sebagai lingkungan pendidikan.

Kondisi lingkungan belajar ini sangat menentukan kelancaran proses pembelajaran misalnya kondisi fisik, lingkungan sosial budaya atau masyarakat, dan lingkungan sekolah. Jika kondisi lingkungan belajar sangat mendukung, maka siswa pun akan lebih bersemangat dalam proses pembelajaran (Aini \& Taman, 2012)

Suasana kelas yang positif akan terjadi bila interaksi dalam kelas terjadi antara dosen dan mahasiswa, dimana dalam interaksi tersebut terjadi komunikasi dalam bentuk belajar bersama, tolong menolong, tenggang rasa antara mahasiswa yang pandai dan kurang pandai, antara yang kaya dan yang kurang mampu, norma-norma pergaulan hidup dan tata tertib kelas maupun kampus dipatuhi dengan fasilitas yang luwes, serta terjadi komunikasi yang terbuka (Dario, 2008).

Lingkungan belajar sangat berperan dalam menciptakan gairah mahasiswa dan secara sosial sangat berpengaruh terhadap proses pembelajaran. Lingkungan belajar dapat meningkatkan keaktifan mahasiswa dan keefektifan belajar. Lingkungan belajar tidak hanya secara langsung mempengaruhi tinggi rendahnya hasil belajar, lingkungan belajar juga akan menyentuh ranah kognitif atau personal siswa (Sumiati, 2012). Dalam proses belajar mengajar, lingkungan merupakan sumber belajar yang berpengaruh dalam keberhasilan proses belajar dan peningkatan perkembangan anak. Tempat dimana kegiatan belajar berlangsung yang mendapatkan pengaruh dari luar terhadap keberlangsungan kegiatan tersebut. Lingkungan yang merupakan sumber 
belajar memiliki pengaruh dalam proses pembelajaran.

Pengamatan yang penulis lakukan saat didalam ruang kelas ternyata ada kesenjangan diantara siswa yang pintar dan siswa yang malas dalam kegiatan belajar. Di kelas terdapat kelompok-kelompok siswa yang berbeda misalnya dalam hal bersosialisasi dengan teman. Terdapat kelompok siswa yang mendominasi kelas dengan pengaruh yang kurang baik dalam hal kegiatan pembelajaran. Kesenjangan yang terjadi adalah dalam mengerjakan dan pengumpulan tugas yang diberikan dosen, beberapa mahasiswa mengerjakan bahkan mengumpulkan tugas tepat pada waktunya sedangkan yang lainnya memang mengerjakan tapi sering berjalan-jalan atau mengobrol dengan temannya sehingga tugas tidak selesai dan tidak dikumpulkan tepat pada waktunya. Mereka yang bergaul dengan kelompok yang malas kemungkinan akan terbawa malas juga tergantung bagaimana siswa itu bisa mengendalikan ego malasnya, sebaliknya mereka yang bergaul dengan kelompok yang rajin kemungkinan besar akan terbawa rajin juga.

\section{Motivasi}

Motivasi biasanya didefinisikan sebagai sesuatu yang memberi energi dan mengarahkan perilaku. Tentu saja ini merupakan definisi umum, definisi yang dapat diaplikasikan untuk banyak faktor yang mempengaruhi perilaku. Kesediaan mahasiswa untuk belajar adalah hasil dari banyak faktor. Mulai dari kepribadian mahasiswa dan kemampuan mahasiswa untuk menyelesaikan tugas-tugas sekolah, hadiah yang didapat karena telah belajar, situasi belajar mendorong mahasiswa untuk belajar dan sebagainya.

motivasi adalah sesuatu yang dapat menimbulkan semangat atau dorongan bekerja individu atau kelompok terhadap pekerjaan guna mencapai kemauan/kebutuhan untik mencapai tujuan tertentu melalui pelaksanaan suatu tugas (Damanik, 2018),

Menurut Muhibbin (2004, 136), motivasi ialah keadaan internal organisme baik manusia ataupun hewan yang mendorongnya untuk berbuat sesuatu. Dalam pengertian ini, motivasi berarti pemasok daya (energizer) untuk bertingkah laku secara terarah.

Dalam kegiatan belajar, motivasi dapat disebut sebagai keseluruhan daya penggerak di dalam diri mahasiswa yang menimbulkan kegiatan belajar yang menjamin kelangsungan dalam kegiatan belajar dan memberi arah sehingga tujuan yang dikehendaki oleh subyek dapat tercapai dengan hasil sebaik-baiknya. Dengan adanya motivasi belajar, maka individu akan tergerak untuk belajar dengan sendirinya. Intensitas motivasi individu akan sangat menentukan tingkat pencapaian prestasi dalam belajarnya.

Dari uraian tersebut dapat disimpulkan motivasi adalah dorongan yang ada dalam diri mahasiswa untuk melakukan kegiatannya sendiri yang berhubungan dengan proses belajar mengajar guna meraih keberhasilan setinggi-tingginya dalam prestasi akademiknya.

\section{METODE PENELITIAN}

Dilihat dari permasalahan yang telah digambarkan pada pendahuluan, maka penelitian ini dapat digolongkan pada penelitian berjenis asosiatif yaitu gambaran informasi lengkap tentang hubungan antar variabel satu dengan gejala lain (X1 berhubungan interaktif dengan dengan X2 dan Y) Sugiono dalam (Damanik, 2019). Penelitian ini memiliki jenis hubungan yang linier karena pada dasarnya hendak melihat hubungan antara variable bebas yaitu minat baca dan peran dosen pembimbing.

Lokasi penelitian akan dilakukan di Kampus AMIK Tunas Bangsa Pematangsiantar, Objek penelitianya adalah "persepsi mahasiswa mengenai kompetensi dosen dan lingkungan belajar terhadap motivasi belajar", sedangkan sample dalam populasi ini sebanyak 81 orang.

\section{Tehnik Pengumpulan Data.}

Tehnik Pengumpulan data dilakukan dengan cara, wawancara, pengisian kuisioner/angket dan studi pustaka yaitu dengan mencari data pendukung dalam penelitian berdasarkan pada buku-buku, literatur-literatur dan penelitian-penelitian sebelumnya yang relevan terhadap objek yang diteliti.

\section{Teknik Analisis Data}

Tehnik analisis data yang digunakan dalam penelitian ini adalah :

\section{Tehnik Analisis Deskriptif.}

Yaitu analisis yang digunakan untuk menganalisis data dengan cara mendeskripsikan atau menggambarkan data yang telah terkumpul sebagaimana adanya, tanpa bermaksud membuat kesimpulan yang berlaku untuk umum atau generalisasi.

\section{Analisis Regresi Linier Berganda.}


Dengan penggunaan teknik Analisis Data Regresi Linier Berganda tersebut, maka formulasi hipotesis yang akan penulis tetapkan.

HASIL \& PEMBAHASAN

\section{Pengaruh Persepsi Mahasiswa Mengenai Kompetensi Dosen Terhadap Motivasi Belajar.}

Untuk mengetahui secara partial pengaruh persepsi mahasiswa mengenai kompetensi dosen terhadap motivasi belajar dapat dilihat pada Tabel 1. dibawah ini.

Tabel 1. Coefficientsa Pengaruh Persepsi Mahasiswa Mengenai Kompetensi Dosen

\begin{tabular}{|c|c|c|c|c|c|c|}
\hline & \multirow{2}{*}{ Model } & \multicolumn{2}{|c|}{$\begin{array}{c}\text { Unstandardized } \\
\text { Coefficients }\end{array}$} & \multirow{2}{*}{\begin{tabular}{|c|}
$\begin{array}{c}\text { Standardized } \\
\text { Coefficients }\end{array}$ \\
Beta
\end{tabular}} & \multirow[t]{2}{*}{$\mathrm{t}$} & \multirow{2}{*}{ Sig. } \\
\hline & & $\mathrm{B}$ & Std. Error & & & \\
\hline \multirow[t]{2}{*}{1} & (Constant) & 14,726 & 3,692 & & 3,988 & 0,000 \\
\hline & $\begin{array}{l}\text { Persepsi Mahasiswa } \\
\text { Mengenai } \\
\text { Kompetensi Dosen }\end{array}$ & 0,189 & 0,056 & 0,286 & 3,353 & 0,001 \\
\hline
\end{tabular}

a. Dependent Variable: MotivasiBelajar- Hasil pengolaha data-2016

Berdasarkan Tabel 1. di atas diketahui bahwa nilai thitung variabel Pengaruh Persepsi Mahasiswa Mengenai Kompetensi
Dosen sebesar 3,353 dan nilai signifikansi 0,001 , sedangkan nilai t-tabel pada tingkat kepercayaan $95 \%(\alpha: 0,05)$

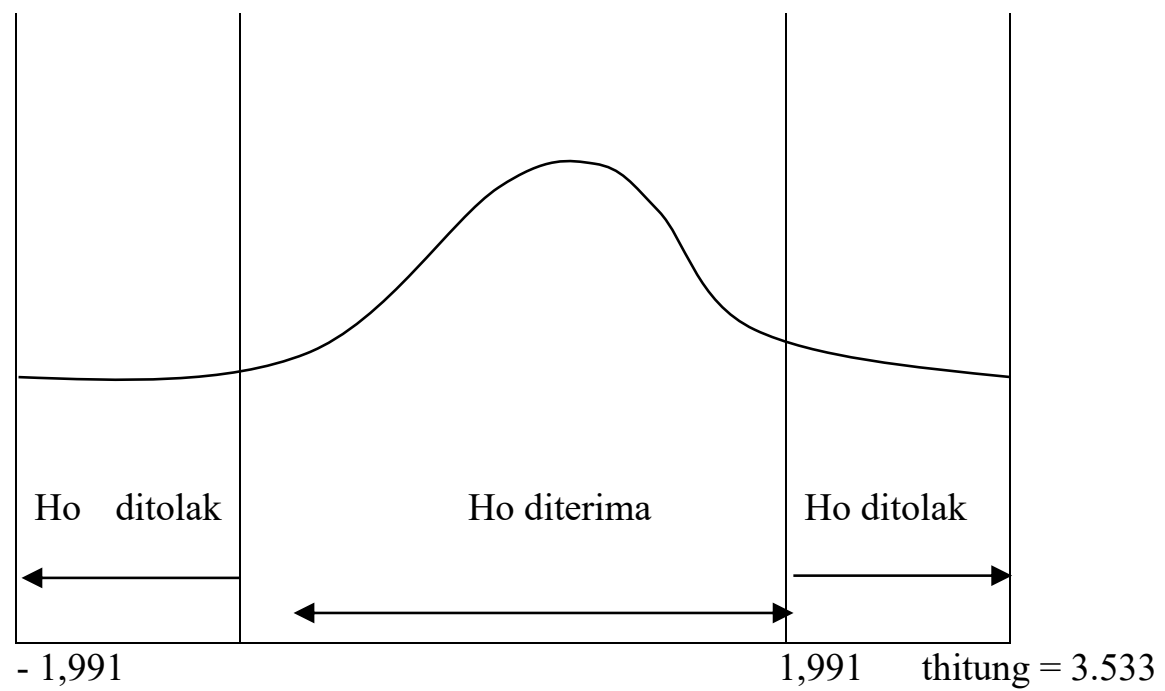

Gambar 1. Uji Persepsi Mahasiswa Mengenai Kompetensi Dosen Terhadap Motivasi Belajar

Dari Gambar 1. diatas diketahui bahwa nilai thitung $>$ ttabel $(3,353>1,991)$ maka diputuskan koefisien regresi signifikan atau $\mathrm{HO}$ ditolak dan menerima hipotesis dalam penelitian ini yaitu variabel persepsi mahasiswa mengenai kompetensi dosen secara partial berpengaruh positif dan signifikan terhadap motivasi belajar

\section{Pengaruh Lingkungan Belajar Terhadap Motivasi Belajar}

Untuk mengetahui secara partial pengaruh lingkungan belajar terhadap motivasi belajar dapat dilihat pada Tabel 2. dibawah ini. 
Tabel 2. Coefficientsa Lingkungan Belajar

\begin{tabular}{|c|c|c|c|c|c|}
\hline \multirow{2}{*}{ Model } & \multicolumn{2}{|c|}{$\begin{array}{l}\text { Unstandardized } \\
\text { Coefficients }\end{array}$} & $\begin{array}{l}\text { Standardized } \\
\text { Coefficients }\end{array}$ & \multirow{2}{*}{$\mathrm{T}$} & \multirow{2}{*}{ Sig. } \\
\hline & B & Std. Error & Beta & & \\
\hline 1 (Constant) & 14,726 & 3,692 & & 3,988 & 0,000 \\
\hline LingkunganBelajar & 0,355 & 0,084 & 0,415 & 4,229 & 0,000 \\
\hline
\end{tabular}

a. Dependent Variable: MotivasiBelajar - Hasil pengolaha data-2016

Berdasarkan Tabel 2. di atas diketahui bahwa nilai thitung variabel lingkungan belajar sebesar 4,229 dan nilai signifikansi

0,000 , sedangkan nilai t-tabel pada tingkat kepercayaan $95 \%(\alpha: 0,05)$

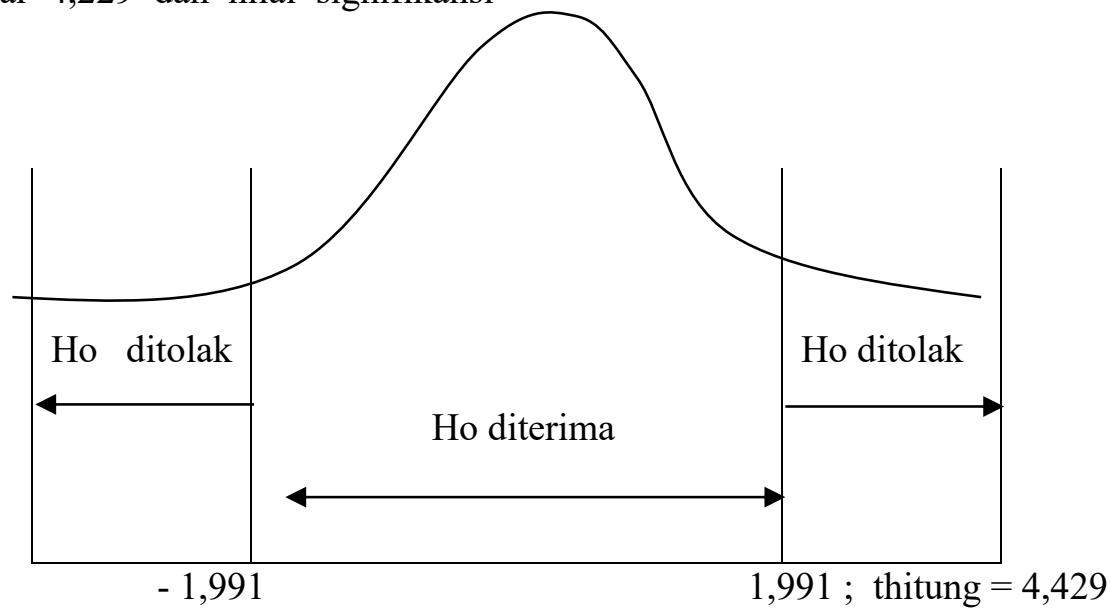

Gambar 2. Uji Lingkungan Belajar Terhadap Motivasi Belajar

Dari Gambar 2. diatas diketahui bahwa nilai thitung $>$ ttabel $(4,229>1,991)$ maka diputuskan koefisien regresi signifikan atau H0 ditolak dan menerima hipotesis dalam penelitian ini yaitu variabel lingkungan belajar secara partial berpengaruh positif dan signifikan terhadap motivasi belajar.

Pengaruh Persepsi Mahasiswa Mengenai Kompetensi Dosen Dan Lingkungan Belajar Terhadap Motivasi Belajar

Tabel 3. Model Summary

\begin{tabular}{|l|r|r|r|r|r|r|r|}
\hline \multirow{2}{*}{$\begin{array}{l}\text { Mode } \\
1\end{array}$} & & & \multirow{2}{*}{$\mathrm{R}$} & \multirow{2}{*}{$\begin{array}{c}\text { Adjusted } \mathrm{R} \\
\text { Square }\end{array}$} & $\begin{array}{c}\text { Std. Error } \\
\text { of the } \\
\text { Estimate }\end{array}$ & \multicolumn{3}{|c|}{ Change Statistic } \\
\cline { 5 - 8 } & & Square & Squange & $\mathrm{df1}$ & $\mathrm{df2}$ \\
\hline 1 & $0,709^{\mathrm{a}}$ & 0,502 & 0,483 & 1,28396 & 0,502 & 25,872 & 3 \\
\hline
\end{tabular}

a. Predictors: (Constant), LingkunganBelajar, Persepsi Mahasiswa Mengenai Kompetensi Dosen

Dari Tabel 3. diatas diketahui bahwa nilai korelasi secara simultan antara Persepsi Mahasiswa Mengenai Kompetensi Dosen, Dan Lingkungan Belajar Terhadap Motivasi
Belajar sebesar 0,709. Nilai korelasi ini dapat dikategorikan pada korelasi yang kuat karena berada pada interval $(0,60-0,799)$. Kemudian untuk membuktikan kebenaran 
hipotesis penelitian atau apakah nilai korelasi itu dapat digeneralisasikan, maka harus diuji signifikansinya dengan uji-F, dan dari pengolahan data diketahui nilai Fhitung sebesar 25,872. Nilai F-hitung ini selanjutnya diinterpretasikan dengan nilai Ftabel dan dengan tingkat kpercayaan 95\% $(\alpha=0,05)$, dengan $\mathrm{dk}$ pembilang $=\mathrm{k}$ dan $\mathrm{dk}$ penyebut $=$ $(\mathrm{n}-\mathrm{k}-1)=81-3-1=77$, maka nilai Ftabel $=2,720$. Jadi dari hasil perhitungan uji signifikan, dapat dilihat bahwa nilai Fhitung $>$ Ftabel yaitu 25,872 > 2,720, jadi hipotesis penelitian secara simultan dapat dibuktikan yaitu terdapat pengaruh positif dan signifikan antara persepsi mahasiswa mengenai kompetensi dosen, dan lingkungan belajar terhadap motivasi belajar.

Selanjutnya untuk mengetahui seberapa besar pengaruh persepsi mahasiswa mengenai kompetensi dosen, dan lingkungan belajar terhadap motivasi belajar maka diuji dengan uji determinan (D). Dari pengolahan data diperoleh nilai $r^{2}$ (Rsquare) sebesar 0,502, maka dapat diketahui nilai Determinannya adalah $0,502 \times 100 \%=50,20 \%$, yang berarti bahwa variabel persepsi mahasiswa mengenai kompetensi dosen dan lingkungan belajar secara simultan berpengaruh terhadap motivasi belajar sebesar 50,20\%, dan sisanya sebesar 49,80\% dipengaruhi oleh faktorfaktor lain yang tidak diteliti.

\section{Analisis Regresi Linier Berganda}

Analisis regresi linier berganda ini digunakan untuk mengestimasi pengaruh persepsi mahasiswa mengenai kompetensi dosen, dan lingkungan belajar terhadap motivasi belajar. Berdasarkan hasil pengolahan data diperoleh hasil sebagai berikut :.

\section{Tabel 4. Hasil Uji Signifikansi Variabel Independent Coefficients $^{\text {a }}$}

\begin{tabular}{|c|c|c|c|c|c|}
\hline \multirow{2}{*}{ Model } & \multicolumn{2}{|c|}{$\begin{array}{l}\text { Unstandardized } \\
\text { Coefficients }\end{array}$} & \multirow{2}{*}{$\begin{array}{c}\begin{array}{c}\text { Standardized } \\
\text { Coefficients }\end{array} \\
\text { Beta }\end{array}$} & \multirow{2}{*}{$\mathrm{T}$} & \multirow{2}{*}{ Sig. } \\
\hline & B & $\begin{array}{l}\text { Std. } \\
\text { Error }\end{array}$ & & & \\
\hline $1 \quad$ (Constant) & 14,726 & 3,692 & & 3,988 &, 000 \\
\hline $\begin{array}{l}\text { PersepsiMahasiswaMengenaiK } \\
\text { ompetensiDosen }\end{array}$ & 0,189 & 0,056 & 0,286 & 3,353 & 0,001 \\
\hline Fasilitas & 0,163 & 0,068 & 0,246 & 2,390 & 0,019 \\
\hline LingkunganBelajar & 0,355 & 0,084 & 0,415 & 4,229 & 0,000 \\
\hline
\end{tabular}

a. Dependent Variable: MotivasiBelajar

Dengan persamaan regresi linier berganda tersebut dapat dijelaskan bahwa:

a. Nilai konstanta adalah sebesar 14,726, hal ini menyatakan bahwa jika persepsi mahasiswa mengenai kompetensi dosen, dan lingkungan belajar diabaikan maka nilai motivasi belajar mahasiswa sebesar 14,726 .

b. Koefisien regresi untuk variabel persepsi mahasiswa mengenai kompetensi dosen sebesar 0,189, hal menunjukkan bahwa setiap kenaikkan $1 \%$ faktor persepsi mahasiswa mengenai kompetensi dosen maka akan meningkatkan motivasi belajar mahasiswa sebesar $1,89 \%$.

c. Koefisien regresi untuk variabel lingkungan belajar sebesar 0,355, hal menunjukkan bahwa setiap kenaikkan 1\% faktor lingkungan belajar maka motivasi belajar mahasiswa akan meningkat sebesar $3,55 \%$. 


\section{KESIMPULAN \& SARAN}

Kesimpulan

Persepsi mahasiswa mengenai kompetensi dosen secara partial berpengaruh positif dan signifikan terhadap motivasi belajar dapat dilihat dari nilai thitung $>\operatorname{ttabel}(3,353>$ 1,991).

Lingkungan belajar secara partial berpengaruh positif dan signifikan terhadap motivasi belajar mahasiswa dapat dilihat dari nilai thitung $>$ ttabel $(4,229>1,991)$.

Persepsi mahasiswa mengenai kompetensi dosen dan lingkungan belajar secara simultan berpengaruh positif dan signifikan terhadap motivasi belajar dapat dilihat dari nilai Fhitung $>$ Ftabel yaitu $(25,872$ $>2,720)$, dan secara prosentase pengaruh variable X1, X2, terhadap Y sebesar 50,20\%, dan sisanya sebesar $49,80 \%$ dipengaruhi oleh faktor-faktor lain yang tidak diteliti.

\section{Saran}

1. Memberikan kesempatan dan mendorong kepada para dosen untuk mengikuti pelatihan-pelatihan, seminar-seminar, workshop-workshop untuk meningkatkan kompetensinya.

2. Mendorong para dosen untuk meningkatkan strata pendidikannya dan memberikan bantuan pendanaannya.

3. Berikan reward kepada dosen yang berprestasi sebagai stimulus agar dosen semakin terpacu untuk meningkatkan kualitas dirinya sebagai pendidik yang kompeten.

Menciptakan lingkungan yang sehat dan kondusif kepada seluruh elemen kampus, baik lingkungan belajar maupun lingkungan pergaulan.

\section{DAFTAR PUSTAKA}

A.M., S. (2001). Interaksi Dan Motivasi Belajar Mengajar (24th ed.). Jakarta: Raja Grafindo Persada.

Aini, P. N., \& Taman, A. (2012). Pengaruh Kemandirian Belajar Dan Lingkungan Belajar Siswa Terhadap Prestasi Belajar Akuntansi Siswa Kelas Xi Ips Sma Negeri 1 Sewon Bantul Tahun Ajaran 2010/2011. Jurnal Pendidikan Akuntansi Indonesia, 10(1), 48-65. https://doi.org/10.21831/jpai.v10i1.921

Damanik, B. E. (2018). Pengaruh Motivasi Dan Pengembangan Diri Terhadap Prestasi Kerja Dosen. Jurnal EK \& BI Politeknik Bisnis Indonesia, 1(1), 23-24.
Damanik, B. E. (2019). Pengaruh Kemampuan Intelektual Dan Motivasi Kerja Terhadap Kinerja Guru. Idaarah: Jurnal Manajemen Pendidikan, 2(2), 143.

Dario, A. (2008). Psikologi perkembangan dewasa muda. Jakarta: Grasindo.

Djamarah, S. B. (2002). Psikologi Belajar. Jakarta: Rineka Cipta.

Muhammad, M. (2017). Pengaruh Motivasi Dalam Pembelajaran. Lantanida Journal, 4(2), 87. https://doi.org/10.22373/lj.v4i2.1881

Saifuddin, M. F. (2018). E-Learning dalam Persepsi Mahasiswa. Jurnal VARIDIKA, 29(2), 102-109. https://doi.org/10.23917/varidika.v29i2.5 637

Sumiati. (2012). Pengaruh Lingkungan Belajar Siswa Terhadap Motivasi Belajar dan Implikasinyat terhadap Hasil Belajar Siswa Pada Mata Pelajaran Ekonomi Syariah Di SMP Kota Tasikmalaya. Jurnal Pendidikan Ekonomi Dan Koperasi, Vol 7, No.

Sunaryo. (2004). Psikologi untuk Keperawatan. Jakarta. 